Volume 11

Issue 1 Information and Communications

Technologies in Mass Atrocities Research and

Article 14

Response

$5-2017$

\title{
Book Review: The Genocide Contagion: How We Commit and Confront Holocaust and Genocide
}

Mark A. Drumbl

Washington and Lee University School of Law

Follow this and additional works at: https://digitalcommons.usf.edu/gsp

\section{Recommended Citation}

Drumbl, Mark A. (2017) "Book Review: The Genocide Contagion: How We Commit and Confront Holocaust and Genocide," Genocide Studies and Prevention: An International Journal: Vol. 11: Iss. 1: 113-114.

DOI:

http://doi.org/10.5038/1911-9933.11.1.1469

Available at: https://digitalcommons.usf.edu/gsp/vol11/iss1/14

This Book Review is brought to you for free and open access by the Open Access Journals at Digital Commons @ University of South Florida. It has been accepted for inclusion in Genocide Studies and Prevention: An International Journal by an authorized editor of Digital Commons @ University of South Florida. For more information, please contact digitalcommons@usf.edu. 


\title{
Book Review: The Genocide Contagion: How We Commit and Confront
}

Holocaust and Genocide

\author{
Mark A. Drumbl \\ Washington and Lee University School of Law \\ Lexington, VA, USA
}

The Genocide Contagion: How We Commit and Confront Holocaust and Genocide

Israel W. Charny

Lanham, Rowman \& Littlefield, 2016

244 Pages; Price: \$38.00 Hardcover

Reviewed by Mark A. Drumbl

Transnational Law Institute, School of Law, Washington and Lee University

"Je Tue, donc Je Suis!

I kill, therefore I Am!

I beat you, Descartes-mine is more powerful.

You die. I live." 1

Professor Israel Charny is an educator, family therapist, scholar, and clinical psychologist. He is among the founders of a discipline that we now call genocide studies. It is with the help of these four rhythmic lines-Charny's own, in fact, a snippet of a longer poem he wrote-that he introduces the reader to his latest courageous effort animated by his desire to understand the perpetrator of atrocity. The Genocide Contagion is an attempt to grasp why people kill and why they imbibe killing as existentially meaningful. "How could they do such a thing?" is Charny's starting point. ${ }^{2}$ Charny's goals in undertaking this task are neither lurid nor voyeuristic. Rather, they are preventative: he seeks to stymie such a cancer from metastasizing in the first place. Charny does not endeavor to understand in order to forgive. His reformulation of Descartes is not one of tout comprendre, c'est tout pardonner. His language is open, but his tone remains firm: without understanding, there cannot be any deterrence.

In this regard, then, Charny's book situates itself within the burgeoning literature of perpetrator studies. One decade ago, in my own work situated within the field of international law, ${ }^{3}$ I grappled with the conundrum that, when it comes to genocide and massive discrimination-based crimes against humanity, it seems that the violence-however deformed-is the product of those who conform to a social norm rather that deviate or depart therefrom. Bystanders and side-standers, moreover, also matter, without them, and without the many much more active collaborators, the furor of the conflict entrepreneurs would never normalize. Approaching these questions from his discipline of psychology, Charny's work also approaches genocide as an ecological, social, and collective phenomenon. Genocide cannot be unspooled without unfurling the effects of the group on the individual. Genocide cannot be meaningfully analyzed without looking at the "psychological processes at the core of the human psyche." ${ }^{\prime 4}$ Again, this is not to excuse or dissipate; this is not to submerge the acts of the individual within the murky occlusion of the group. Rather, the purpose is to deracinate the etiology of mass atrocity.

In my opinion, the core contribution of Charny's book is to examine the linkages between violence in "everyday life" and violence in extraordinary times. Charny guides his reader through the connections between the cruel spouse, the indifferent bureaucrat, the abusive parent, the smallminded boss, and the narcissistic academic on the one hand, and the functionary of atrocity, on the other. By focusing on the harshness of human agency in the everyday, Charny calls in to question

\footnotetext{
${ }^{1}$ Israel W. Charny, The Genocide Contagion: How We Commit and Confront Holocaust and Genocide (Lanham: Rowman \& Littlefield, 2016), 20.

${ }^{2}$ Ibid., 23.

${ }^{3}$ Mark A. Drumbl, Atrocity, Punishment, and International Law (Cambridge, UK: Cambridge University Press, 2007).

${ }^{4}$ Charny, The Genocide Contagion, 31.
} 
the uniqueness of genocide. He reminds us that when we intone "never again" it is because that "again" could happen anywhere and, in fact, happens in little bits and pieces in ordinary time in the blandest and balmiest of moments. Thwarting hatred in public life begins by purging hatred in private life. Charny's bold fusion of the extraordinary to the everyday, of the massive to the mundane, shatters scale in favor of substance, just as it favors cause over effect. Charny's efforts are groundbreaking in coming to terms with the psychology of mass violence.

Charny's book achieves three major goals. First, it elucidates why people inflict grievous pain upon others, and how the social kinetics of this pain become contagious, like a virus: a spreading, thickening stain that gives rise to the book's title. It is here that the book contributes great heft and gravitas to the "new" field of perpetrator studies, championed elsewhere by scholars such as Christopher Browning, Vahakn Dadrian, Alex Hinton, Alette Smeulers, and Barbora Holá. Second, Charny's book obliges the reader to question him or herself in the everyday, to assess his or her own quotidian lapses and agencies, with a view to interrogate whether the concatenation of daily duplicities, "creative deceit," ${ }^{5}$ and imposed humiliations could, in turn, gel into a fertile basis for extirpation. Charny actualizes these moments of reflective rumination through his deployment of a number of exercises (independent study questions) and thought experiments in which he invites the readers' participation. Thirdly, Charny makes it clear that, although genocide is a social tragedy contoured by the collective, the elements that fuel genocide are not culturally reductionist these elements, and discomfiting glimmers thereof, can arise anywhere and everywhere. Charny's courageous work on attitudes of Israeli students and soldiers, ${ }^{6}$ his advocacy for the universal need to condemn all genocides, and his exposition of the horrors of denialism(s) ground a book that challenges, compels, and convinces all at once.

Charny does not explore all types of perpetrators. One type that slips through his book is the victim who victimizes others. Members of the persecuted group may come, largely by coercion and survivalism, but also by opportunism to persecute other members. Here is the "grey zone," of which Primo Levi eloquently wrote and of which Tim Blake Nelson made a haunting film of the same title in 2001. Nelson's film portrays Sonderkommando Group XII. This group led a rebellion at Auschwitz that destroyed several of the crematoria, yet all the while its' members eked out more months of life and alcohol and unheard of rations in exchange for their services incinerating the bodies of the dead who while alive they had led into "delousing." Other than a series of trials of Kapos and ghetto police held in Israel in the 1950's and 1960's, the role of the oppressed in "prisoner self-administration" in the Nazi camps has been poorly understood by law. It is Levi, and other expositors of the iniquities of Auschwitz, who have addressed the phenomenon of these utterly compromised perpetrators. Perhaps psychology has something to contribute as well.

Delivered in lively, accessible, and approachable format, The Genocide Contagion is suitable for a broad array of audiences and learners. Charny neither minces words nor overloads (or overlords) with agony. His work is neither human rights stenography nor human rights pornography. Charny emphasizes the capacity of the human spirit to harm and to recover, to injure and to atone: and, all the while, he maintains a cool faith in the power of pedagogy, prevention, and perseverance in draining the contagiousness of genocide and ultimately eradicating this blight upon humanity.

\footnotetext{
${ }^{5}$ Ibid., 136.

${ }^{6}$ Set out in the Appendix, pp. 185-197.
} 